ORCID: 0000-0001-7883-6244

Uniwersytet Kazimierza Wielkiego w Bydgoszczy

ewafil@ukw.edu.pl

\title{
Społeczne podstawy poznania i rozwoju - konstruktywizm społeczno-kulturowy Lwa S. Wygotskiego. Nowe odczytania, rekonstrukcje, tropy epistemologiczno-metodologiczne
}

\section{Summary \\ The social foundations of cognition and \\ development - socio-cultural constructivism of Lev S. Vygotsky. \\ New readings, reconstructions, epistemological and methodological traces}

The original concept, theory-method of Lev S. Vygotsky, the innovative nature of his views allows to adopt new theoretical and methodological tools to describe the process of development and learning of a child, reconstruct what is happening in the classroom and in the students' minds. For many years the interest in Vygotsky's concept has been experiencing a renaissance all over the world, also in Poland. The cognitively sophisticated concept has original terminology. Unfortunately, in the discourses, frequent borrowings and loose usage of terms have been observed, as well as the reproduction of Vygotsky's words without discovering the meaning or giving them a deeper meaning. As a consequence, this brings the risk of distortion of the idea and the apparent change of school culture, its opening to a new quality (socio-cultural constructivism). In this article I share my reflection on: research and Research and Development (R\&D) activities based on the theory-method of L.S. Vygotsky, applying his ideas to pedagogical research, and educational implications for changing everyday teaching practice.

Keywords: socio-cultural constructivism, the theory-method of Lev S. Vygotsky, social development situation, semiotic mediation, indirect learning, formative activity/educational activity

Słowa kluczowe: konstruktywizm społeczno-kulturowy, teorio-metoda Lwa S. Wygotskiego, społeczna sytuacja rozwoju, mediacja semiotyczna, upośredniane uczenie, formatywna aktywność/działalność edukacyjna

\section{Wprowadzenie}

Współczesny dyskurs dotyczący natury dziecięcego myślenia i uczenia się, tworzenia się wiedzy w umyśle dziecka, rekonstruowania tego, jak dzieci uczą się i myślą, jak poznają rzeczywistość, zdominował paradygmat konstruktywistyczny, przynosząc nowe narzędzia 
teoretyczne do opisu procesu rozwoju i uczenia się oraz tego, „,co się dzieje w klasie szkolnej i w umyśle uczniów" (por. podejścia metodologiczne) (Filipiak 2018a; Zwiernik 2015). Konstruktywizm ma wiele odmian i wariantów (społeczny, radykalny, epistemologiczny, systemowy, historyczny i wiele innych), ale wspólne jest: założenie dotyczące procesu tworzenia wiedzy w umyśle, podkreślanie znaczenia wiedzy osobistej uczniów i ich samodzielności w dochodzeniu do rozumienia, zwrócenie uwagi na ciągłe poszerzanie i udoskonalanie narzędzi reprezentowania i operowania wiedzą (Stemplewska-Żakowicz 1996; Dylak 2000; Gołębniak 2005; Klus-Stańska 2018). Warunkiem koniecznym rozwoju i uczenia się w paradygmacie konstruktywistycznym jest aktywność własna/ działalność jednostki (Zuckerman 2003; Karpov 2014; Klus-Stańska 2018). Najskuteczniejsze uczenie się następuje we współpracy z innymi wtedy, kiedy „,...) jest ono partycypacyjne, proaktywne, wspólne, kooperatywne i nastawione raczej na tworzenie znaczeń niż na ich przyjmowanie w gotowej postaci (...)" (Bruner 2006: 122). Obraz świata w umyśle jest aktywnie konstruowany przez poznający podmiot, a na jego ostateczny kształt wpływają zarówno zinternalizowana informacja zewnętrzna, własności aparatu poznawczego jednostki, dotychczasowe instrumentarium i narzędzia poznania, którymi jednostka dysponuje, jak i zgromadzona wcześniej wiedza uprzednia (Stemplewska-Żakowicz 1996).

Paradygmat konstruktywistyczny w naturalny sposób wymusza konieczność zmiany myślenia nauczyciela o dziecku, przemyślenia na nowo jego teorii umysłu dziecka. Warto przywołać tutaj myśl Jerome’a S. Brunera, który w książce Kultura edukacji postawił tezę: „(...) u podstaw praktyk edukacyjnych w klasach szkolnych leży zbiór zdroworozsądkowych przeświadczeń o umysłach uczniów, z których część działa w sposób zamierzony dla dobra, a część niezamierzenie przeciwko dobru dziecka. Należy je wypowiedzieć otwarcie i zrewidować. Rozmaite podejścia do uczenia się i różne formy nauczania - od instrukcji do nauczania poprzez dokonywanie odkryć oraz współpracy - odzwierciedlają zróżnicowane przekonania i przeświadczenia o uczniu - od aktora do znawcy, osobiście doświadczającego, współpracującego myśliciela. (...) Postępy w rozumieniu dziecięcych umyslów są zatem warunkiem wstępnym jakiegokolwiek postępu w pedagogii” (Bruner 2006: 78, podkr. - E.F.).

Bruner wskazuje cztery współcześnie funkcjonujące modele umysłu ucznia, określające sposób nauczania i ,edukacji”, uwzględniające relacje pomiędzy nauczycielem a uczniem. Postrzega się w nich dzieci jako:

- uczących się przez naśladowanie: nabywanie umiejętności praktycznych (wiedza proceduralna - „wiem jak”);

- uczących się wskutek ekspozycji na działania dydaktyczne: nabywanie wiedzy deklaratywnej (,wiem, że");

- myślących: rozwój wymiany intersubiektywnej;

- wiedzących: zarządzanie wiedzą obiektywną (Bruner 2006; Filipiak 2011: 95-96).

Nauczycielskie teorie dziecka rozstrzygają o charakterze praktyk edukacyjnych realizowanych w klasach szkolnych w rozmaitych kontekstach kulturowych. Zmiana myślenia nauczycieli wiąże się z przyjęciem innej perspektywy, zmiany rozumienia statusu 
dziecka oraz własnej roli w kulturze klasy szkolnej (z kierowniczej roli ukierunkowanej na transmisję i reprodukcję dominującej kultury do roli organizatora i badacza warunków uczenia). Tak jak zmienia się „teoria dziecka u nauczyciela”, postrzeganie dziecka jako myślącego, zdolnego do rozumowania, znajdowania sensu w wyniku własnych poszukiwań bądź przy pomocy dorosłego (lub we współpracy z nim), zdolnego do refleksji, posiadającego własną „teorię” na temat funkcjonowania świata, własnego umysłu, tak zmienia się poziom i typ wykonania, jakiego oczekuje nauczyciel od dziecka, wyłania się całkiem odmienny obraz jego kompetencji (Brown, Ferrara 1994; Bruner 2006; Filipiak 2011).

Pozostaje pytanie, na które warto poszukiwać odpowiedzi: Czy ta zmiana myślenia nauczycieli o edukacji oparta na fundamentach konstruktywizmu się dokonała? Analizując dyskursy obecne w przestrzeni publicznej i w publikacjach, dokumentację aplikowanych projektów edukacyjnych, można uznać, że konstruktywizm jest wszechobecny i stał się nowym ,uprawomocnieniem podejmowanych przez nauczycieli praktyk edukacyjnych" (Gołębniak 2005: 13). Niestety w praktyce edukacyjnej ta deklarowana zmiana jest często pozorna, występuje jedynie w terminologii, jest zaś nieobecna w codziennych praktykach nauczycieli, w etnografii klas szkolnych, w kulturze uczenia czy w teorii umysłu nauczycieli.

Dorota Klus-Stańska, badaczka konstruowania wiedzy w szkole, istniejących w niej barier i ograniczeń, stwierdziła, że w klasach początkowych stosuje się model edukacji niezgodny z wiedzą psychologiczną. Kilkuletnie przebywanie i uczestniczenie w takiej kulturze uczenia prowadzi do zmian w umyśle ucznia i niestety nie zawsze są to zmiany korzystne. Jej zdaniem szkoła oferuje dzieciom warunki uczenia się niezgodne z ich specyfiką rozwojową i mechanizmami uczenia się. Wskutek takich działań szkoła jest nieczytelna rozwojowo, wsteczna (zatrzymuje dzieci w rozwoju, nie tworzy wyzwań) lub nawet deformacyjna (Klus-Stańska 2008). Stosowane przez nauczycieli strategie i oferowana im droga uczenia się wygasza działania eksploracyjne uczniów i odwagę ujawniania swoich przekonań, tłumi „apetyt na wiedzę”, a w konsekwencji - zamiast wspierać rozwój umysłowy ucznia, zaniedbuje i ogranicza rozwój kompetencji dla niego istotnych, „amputuje rozum” (Klus-Stańska 2008: 43). Alternatywą dla takiej szkoły jest szkolna kultura uczenia się oparta na: kulturowo-historycznej teorii Lwa S. Wygotskiego, teorii nauczania rozwijającego Dawidowa, rozwijająca myślenie rozumowe ucznia, samodzielność w myśleniu i działaniu, internalizująca proces uczenia się i narzędzia (Zuckerman 2003), tworząca warunki dla rozwijania myślenia teoretycznego. W artykule dzielę się refleksją wynikającą z wieloletnich „spotkań” z teorio-metodą Wygotskiego, odczytywania założeń jego socjo-historyczno-kulturowej teorii rozwoju wyższych funkcji psychicznych i tworzenia fundamentów rozumienia konstruktywizmu mającego implikacje dla zmiany myślenia o edukacji i rozwoju. 


\section{Paradygmat społeczno-kulturowy L.S. Wygotskiego: ramy, fundamentalne kategorie, założenia}

Aby zrozumieć teorio-metodę Wygotskiego, stworzony przez niego oryginalny system teoretyczny, nowatorstwo poglądów i w konsekwencji - przyjąć nowe narzędzia teoretyczne do opisu procesu rozwoju i uczenia się, trzeba przede wszystkim zrozumieć i odkryć sens fundamentalnych kategorii oraz relacji między nimi (filtr interpretacyjny). Ta zmiana myślenia i przyjęcie ,paradygmatu Wygotskiego” (tab. 1) są ważne zarówno w odniesieniu do profesjonalnych badaczy, którzy wybierając teorio-metodę Wygotskiego, decydują się na podejście badawcze (metoda mikrogenetyczna, podwójnej stymulacji, eksperyment nauczający) (Filipiak 2018a), formułują założenia oraz konstrukty teoretyczne, jak również w odniesieniu do nauczycieli, refleksyjnych praktyków, badaczy własnej praktyki, którzy budują rozwojową sytuację społeczną, ich samoświadomości dydaktycznej.

Tabela 1. Paradygmat społeczno-kulturowy L.S. Wygotskiego: ramy, fundamentalne kategorie, założenia

\begin{tabular}{|c|c|}
\hline Kryterium & Opis \\
\hline Fundamentalne kategorie & $\begin{array}{l}\text { społeczna sytuacja rozwoju, „działalność/aktywność } \\
\text { uczącego się podmiotu”; strefa najbliższego/strefa aktualnego } \\
\text { rozwoju; instrukcja formatywna; wyższe funkcje psychiczne, } \\
\text { teoria nauczania rozwijającego, usensowione przeżywanie, } \\
\text { narzędzie i znak }\end{array}$ \\
\hline Rozumienie uczenia się & $\begin{array}{l}\text { uczenie się jest wspólną aktywnością dziecka i nauczyciela } \\
\text { w strefie rozwoju; aktywność/działalność edukacyjna } \\
\text { (learning activity) }\end{array}$ \\
\hline Rodzaje wiedzy & $\begin{array}{l}\text { wiedza empiryczna vs wiedza teoretyczna - wiedzę empiryczną } \\
\text { dziecko może zdobyć samodzielnie, lokuje się w Strefie } \\
\text { Aktualnego Rozwoju, natomiast wiedza teoretyczna jest } \\
\text { konstruowana w Strefie Najbliższego Rozwoju, jej tworzenie jest } \\
\text { możliwe wyłącznie przy współpracy z dorosłym }\end{array}$ \\
\hline Droga uczenia się & $\begin{array}{l}\text { „od abstrakcji do konkretu”, opanowanie metody naukowego } \\
\text { poznania }\end{array}$ \\
\hline Mechanizmy & $\begin{array}{l}\text { upośredniane uczenie się, mediacja semiotyczna, „wrażliwe } \\
\text { nauczanie”, budowanie rusztowania, internalizacja, od działania } \\
\text { ze wsparciem do działania samodzielnego; „od regulacji przez } \\
\text { innych do samoregulacji”, „od cudzej pomocy do autopomocy”, } \\
\text { „modelowanie” }\end{array}$ \\
\hline Status i rola ucznia & „praktykant”; agent zmiany samego siebie, „samosterowny” \\
\hline Status i rola nauczyciela & $\begin{array}{l}\text { organizator warunków uczenia się, mediator, pośrednik, } \\
\text { „wrażliwy” zarówno na osiągnięcia dziecka, jak i potencjał jego } \\
\text { możliwości, ujawnia typy aktywności: wspieranie, pomaganie, } \\
\text { prowokowanie/wyzwanie }\end{array}$ \\
\hline
\end{tabular}

Źródło: opracowanie własne. 


\section{Społeczna natura poznania/ społeczna sytuacja rozwoju i uczenia się}

Według Wygotskiego społeczne interakcje w rozwoju dziecka spełniają formatywną rolę i konstruktywną funkcję. Asymetryczna interakcja z dorosłymi, nośnikami kultury, jest najważniejszym czynnikiem rozwoju dziecka. Przez pośrednictwo „innych” (partnerów w interakcji) dziecko podejmuje działania ,uczące”. W tej interakcji podstawową rolę odgrywają znaki i różne semiotyczne systemy. Szczególną rolę „pośrednika” między uczeniem a rozwojem pełni język. Wygotski mówi o planującej funkcji mowy, która umożliwia dziecku przesunięcie czynności z planu interpsychicznego na intrapsychiczny (Filipiak 2012: 41-44; Filipiak (red.) 2015: 26-29). We współczesnych badaniach prowadzonych w paradygmacie kulturowo-historycznym wiele uwagi poświęca się instrukcji formatywnej, która stanowi swoisty „surowiec” uczenia się i rozwoju (Giest 2001). Interakcje społeczne mają „uczący” charakter, ulokowane są w niej źródła refleksji i inteligentnej samoregulacji (Wood 1995; Zuckerman 2003). Można powiedzieć, że interakcje społeczne podejmowane w kulturze szkoły i celowo organizowanych tam warunkach są uwikłane w rozwój zdolności dziecka do samoregulacji i w ten sposób sprzyjają kształtowaniu się u niego pojęcia „siebie jako ucznia”, rozwijania samodzielności jego myślenia, działania i uczenia. Dziecko internalizuje proces uczenia (Wood 1995; Zuckerman, Vengier 2015).

W szczególności wyższe funkcje psychiczne (uwaga dowolna, pamięć logiczna, werbalne i pojęciowe myślenie) ujawniają się i formują w procesie konstruktywnej wzajemnej interakcji (Ivić 2000). Wygotski sformułował ogólne, genetyczne prawo rozwoju kulturowego: „(...) każda wyższa funkcja psychiczna pojawia się w rozwoju dziecka dwukrotnie: raz jako działalność zespołowa, społeczna, czyli jako funkcja interpsychiczna, drugi raz jako działalność indywidualna, jako wewnętrzny sposób myślenia dziecka, jako funkcja intrapsychiczna" (Wygotski 1971: 432). Ta często cytowana teza Wygotskiego nie jest niestety źródłem refleksji inicjującej projektowanie edukacyjne w kulturze współczesnej szkoły i w myśleniu nauczyciela.

Aby edukacja stała się rozwojem zgodnie z myślą Wygotskiego, konieczna jest nie tylko przemiana kultury szkoły w kulturę wzajemnego uczenia (por. późniejsze stanowisko Brunera (2006)), ale też zrozumienie treści innej ważnej kategorii obecnej w jego koncepcji - społecznej sytuacji rozwoju. Społeczną sytuacją rozwoju Wygotski nazywa specyficzny, niepowtarzalny, jedyny, wyjątkowy stosunek, jaki zachodzi pomiędzy dzieckiem a otaczającym je środowiskiem. Zdaniem Wygotskiego społeczna sytuacja rozwoju jest punktem wyjścia dla wszystkich dynamicznych zmian, które zachodzą w rozwoju w danym okresie. Określa formy, drogę, przekształcanie tego, co najpierw jest społeczne, w działanie indywidualne jednostki (Smykowski 2000b: 10; Wygotski 2002: 78). Oddajmy głos Wygotskiemu: „(...) dziecko stanowi część sytuacji społecznej, a stosunek jego do otoczenia i otoczenia do niego zawarty jest w przeżyciach oraz działalności samego dziecka" (Wygotski 2002: 174-175; podkr. - E.F.).

Sens oryginalnej teorii Wygotskiego odnajdujemy zatem także w jego podejściu kontekstualnym, którym zainicjował współcześnie prowadzone międzykulturowe badania 
empiryczne (Rogoff 2003; Hedegaard, Fleer 2013). Wygotski zwraca uwagę na konieczną głęboką analizę ,przeżyć” dziecka zanurzonego w kontekście, badanie środowiska, które „przenika do wnętrza samego dziecka”, próbę określenia natury kontekstu, w jakim przebiega rozwój, i sposobu oddziaływania tego kontekstu na dzieci, a nie skupianie się wyłącznie na zewnętrznych warunkach rozwoju (Wygotski 2002: 175). Dziecko jest elementem kultury społecznej (kultury klasy szkolnej, szkolnego środowiska uczenia) i jego rozwój jest nierozerwalnie związany z tą kulturą. Podstawową jednostką analizy w dyskursie dotyczącym poznania natury myślenia i uczenia się dziecka musi być „dziecko w kontekście”, a nie „dziecko w próżni” (Schaffer 2005: 240-241).

Pytanie, które warto w tym miejscu postawić, dotyczy właściwości kreowanej społecznej sytuacji rozwoju dzieci w wieku wczesnoszkolnym; to pytanie o właściwości kultury szkoły. Jakie są właściwości dyskursu i społecznej interakcji uczącej w przestrzeni szkoły? Ucząca działalność (learning activity), która staje się podstawową, centralną formą aktywności dziecka w wieku wczesnoszkolnym, jest fundamentem procesu uczenia się i rozwoju myślenia. Doświadczenia edukacyjne dzieci z tego okresu mają wpływ na budowanie pojęcia siebie jako ucznia (potwierdzają to w badaniach mikrogenetycznych Galina Zuckerman i Aleksander Vengier (2015)).

\section{Uczenie sie}

Uczenie się w teorii Wygotskiego jest wspólnie podejmowaną aktywnością/działalnością dziecka i nauczyciela w strefie rozwoju, wspólnym tworzeniem znaczeń (Filipiak 2012). Tak rozumiane uczenie się zachodzi na co najmniej dwóch poziomach: inter- i intrapsychicznym (Wood 2006: 91). Dzięki współpracy z dorosłym dziecko nie tylko odkrywa sposoby rozwiązywania zadania, dziedziczy rozwinięte w danej kulturze narzędzia, sposoby myślenia i uczenia się, wyrabiając przy tym coraz większą biegłość, osiąga cel, realizując system dostosowanych do poziomu wykonania różnych typów zadań ${ }^{1}$. Internalizuje uczenie, narzędzia i techniki. Specyficzną kategorią o złożonej treści (zawartości), osadzonej w kulturowo-historycznym podejściu, jest ucząca się działalność, aktywność edukacyjna (learning activity), która jest podstawą (fundamentem) procesu uczenia się i rozwoju myślenia, opanowania metody naukowego poznawania. Koncepcja i pojęcie „uczącej działalności” pojawiły się wraz z eksperymentalnymi badaniami Daniela Elkonina (1989) i Wasilija Dawidowa (1996). Wieloletnie badania Dawidowa nad „uczącą działalnością” jako podstawą rozwoju myślenia teoretycznego współcześnie kontynuuje wielu badaczy. Zuckerman i Vengier w dziesięcioletnim longitudinalnym eksperymencie dokonali mikro-

\footnotetext{
1 „Wrażliwe nauczanie” w podejściu Wygotskiego, Dawidowa i Elkonina opiera się na sekwencji działań, którą można określić jako przejście od „cudzej pomocy do autopomocy”. Procesualne ujęcie zadań umożliwiających przesunięcie działania z obszaru Strefy Najbliższego Rozwoju do Strefy Aktualnego Rozwoju obejmuje zadania: Możliwości („chcę, potrafię z Twoją pomocą”), Kompetencje („wiem jak, spróbuję sam), Poczucie kompetencji (wiem jak, potrafię sam). Szerzej charakterystykę typów zadań podejmuje Ewa Filipiak (2015: 33-35).
} 
analizy rozwoju samodzielności w uczeniu, opisali przejawy inicjatywy aktywności uczących się dzieci, właściwości ich refleksyjnego myślenia i uczenia się. Zdaniem badaczy zdolność do czynienia refleksji jest nie tylko darem, zdolnością dzieci utalentowanych (uzdolnionych). Tworząc odpowiednie warunki i wprowadzając system działań, możemy rozwinąć refleksyjność i samosterowność u wszystkich uczniów (Zuckerman 2003; Zuckerman, Vengier 2015). Teza Wygotskiego, że nauczanie nie tylko może, ale powinno wieść za sobą rozwój dziecka, została przeniesiona w Rosji na opracowanie teorii „,nauczania rozwijającego" (теорияразвивающего обучения) i koncepcji znanej pod nazwą „system Elkonina-Dawidowa”. Koncepcja ta zakłada, że w nauczaniu rozwijającym umysł jednostki niezbędne są rozwijanie myślenia teoretycznego, refleksyjności uczniów, opanowanie metody i narzędzi naukowego poznania. Obiektem działalności uczniów powinny być nie przedmioty, ale sposoby przeprowadzania w nich zmian, które pozwalają na odkrywanie istotnych właściwości tych przedmiotów (Elkonin 1989; Dawidow 1996)².

\section{Droga konstruowania wiedzy}

„(...) Tak więc centralnym momentem dla całej psychologii nauczania jest to właśnie, że dzięki współpracy można dźwignąć się na wyższy stopień możliwości intelektualnych, że dziecko może dzięki naśladowaniu przejść od tego, co umie, do tego, czego nie umie. $\mathrm{Na}$ tym polega znaczenie nauczania dla rozwoju, to w zasadzie jest treścią pojęcia strefy najbliższego rozwoju. (...) Innymi słowy to, co dziecko umie robić dziś przy współpracy, jutro potrafi zrobić samodzielnie" (Wygotski 1989: 253, podkreśl. - E.F.).

Budując społeczną sytuację uczenia się nauczyciel swoje działania kieruje na strefę najbliższego rozwoju, umożliwiając dziecku doświadczanie spotkań z kulturą. Najpierw asystuje i staje się partnerem uczącego się dziecka we wspólnie podzielanych działaniach, a później organizatorem warunków procesu uczenia się (Ivić 2000). Ten specyficzny rodzaj interakcji społecznej pomiędzy uczącym się dzieckiem a dorosłym, który „wie więcej”, ma świadomość problemu, zadania będącego przedmiotem wspólnego, podzielanego zainteresowania metaforycznie nazywamy budowaniem rusztowania (Wood 1995). Budowanie rusztowania jest procesem uczenia się responsywnego (pod kierunkiem dorosłego i we współpracy z nim), który przebiega według ,podzielanych wspólnie programów działania”. Jest układem dynamicznym, polega na wzajemnym „dostrajaniu” udziałów ucznia i nauczyciela, zmieniającej się aktywności zarówno ucznia, jak nauczyciela (Filipiak (red.) 2015). Strategia budowania rusztowania jest strategią pomagania dziecku w osiąganiu samodzielności wykonania zadania, uruchamiania jego refleksji i planowania

\footnotetext{
2 Od 2015 r. badania ukierunkowane na możliwości rozwijania myślenia teoretycznego u dzieci w młodszym wieku szkolnym są prowadzone także w Katedrze Dydaktyki i Studiów nad Kulturą Edukacji Uniwersytetu Kazimierza Wielkiego w Bydgoszczy pod kierunkiem Ewy Filipiak. Badania zostały zainicjowane organizacją eksperymentu nauczającego (www.ack.edu.pl) (Filipiak (red.) 2015), w którym monitorowano proces rozwiązywania specjalnie skonstruowanych zadań rozwojowych stawianych dzieciom w naturalnym środowisku klas na pierwszym etapie edukacji szkolnej (Filipiak 2018a, b).
} 
działań. To strategia upośredniania uczenia się̧ . Upośrednianie ma wiele wymiarów (upośrednianie znaczenia), można wskazać upośrednianie: poczucia kompetencji, regulacji zachowania, transcendencja (wykraczanie poza dostępne informacje) i form (upośrednianie przez drugiego człowieka, przez narzędzie, przez znak, przez znaczenie słowa), które czynią tę drogę dochodzenia do samodzielności w działaniu dziecka specyficzną (Smykowski 2000b). Nauczyciel (tutor) tworzy społecznie zaangażowaną sytuację uczenia, warunki do rozwiązania zadania, przestrzeń inicjatywnej współpracy, „,uruchamia” funkcjonowanie dziecka, podtrzymuje dziecięcą inicjatywę, pomaga mu w osiągnięciu celu zadania. Doprowadza do rozwiązania zadania etapami dzięki wsparciu i podawaniu właściwych instrukcji. Ważne jest, aby nauczyciel/tutor nie skracał drogi rozumowania i nie doprowadzał do zbyt pospiesznego uogólnienia. Daje dziecku czas na myślenie, rozumowanie i wnioskowanie. Strategię budowania rusztowania cechują: 1) wzajemność procesu uczenia się; 2) specyficzna rola dziecka, które najpierw jest „praktykantem” u tutora posiadającego większą wiedzę, a dopiero potem staje się , ,agentem zmiany samego siebie”, samosterownym i samodzielnym w działaniu; 3) rola nauczyciela ujawniającego zmieniające typy aktywności (wspieranie, pomaganie, prowokowanie/stawianie wyzwań) ${ }^{4}$; 4) określone warunki budowania sytuacji uczenia się (Filipiak 2015a: 19-21). Można powiedzieć, że konstruując wiedzę i rozumienie, dziecko niejako „,...) »pożycza« dojrzalszą świadomość nauczyciela, by z jej pomocą operować treściami, których jego umysł samodzielnie nie byłby jeszcze zdolny ujmować" (Stemplewska-Żakowicz 1996: 39).

W dynamicznie organizowanej sytuacji społecznej interakcji uczącej, w zależności od tego, gdzie „dzieje się" proces nauczania-uczenia się (w strefie najbliższego czy aktualnego rozwoju), dziecko doświadcza różnych typów uczenia się (instruction, teaching, tuition, learning) (Wood 1995; Filipiak 2015a). W każdym z nich zmienia się zakres pomocy udzielanej dziecku, zakres świadomości i kontroli. Wśród mechanizmów charakteryzujących to „wrażliwe nauczanie” można wymienić: modelowanie, upośrednianie, mediację semiotyczną, przejście „od działania ze wsparciem do działania samodzielnego”, „od regulacji przez innych do samoregulacji”, ,od cudzej pomocy do autopomocy”. Rozwijanie samodzielności w uczeniu się dziecka pozwala na stawanie się uczniem samosterownym (Filipiak 2012; Zuckerman, Vengier 2015). Wracając do myśli zawartej w cytowanym wcześniej fragmencie pracy Wygotskiego, zwracam uwagę na pułapkę znaczeń, które przypisuje się występującej w cytacie kategorii „naśladownictwo” i „modelowanie”. W rozumieniu Wygotskiego to nie są leksykalne tropy behawioralne charakterystyczne dla dydaktycznej strategii wdrożeniowej, kierującej uwagę na drogę „,wiedzy zdobywanej po śladach dorosłego" (terminologia D. Klus-Stańskiej). Uczenie się w koncepcji Wygotskiego jest dystrybuowane, interaktywne, kontekstualne i opiera się na uczestnictwie we wspólnie podzielanych praktykach nauczyciela i uczniów. Ma charakter transformacyjny,

\footnotetext{
3 Zachowania dorosłego-mediatora między dzieckiem a otoczeniem oraz właściwości interakcji dziecko-dorosły szerzej charakteryzuje Anna Brzezińska (2000: 94-95).

4 Typy aktywności nauczyciela i właściwości interakcji szerzej przedstawia Filipiak ((red.) 2015: 22-24).
} 
nie transmisyjny. Dziecko przyswaja aktywności strukturujące i samoregulacyjne poprzez interakcję z dorosłym, który we wrażliwy sposób kieruje jego aktywnością/działalnością uczącą związaną z rozwiązywaniem problemów ukrytych w zadaniach, strukturyzuje środowisko uczenia się, dostarcza pomocy i dostosowuje poziom wsparcia. Zmienia obraz (przekształca warunki) zadania i współtworzy nowe środki do osiągnięcia celu, nadaje znaczenie informacjom docierającym do dziecka, pomaga dzieciom w rozumieniu, buduje „mentalne mosty”. Nauczyciel posiada „mapę działania”, informację i wskazówki, jak korzystać z mapy i eksplorować teren, ale prowadząc dziecko do celu, wybiera różne drogi w zależności od „udziału” i zaangażowania dziecka. To „podążanie za dzieckiem” wymaga zarówno dostrzegania i podtrzymania dziecięcej inicjatywy (Zuckerman 2003), jak i diagnozy potencjału rozwojowego dziecka (Smykowski 2000a). „Mówiąc językiem Wygotskiego, nauczyciel musi umieć określić sferę najbliższego rozwoju dziecka i pracować na jej granicy, monitorując działania dziecka przy użyciu metody kolejnych przybliżeń, aby upewnić się, czy sprosta ono stawianym mu wymaganiom i dołoży wszelkich starań, by je spełnić, nie zostając samo z wyzwaniami przekraczającymi jego aktualny poziom zdolności. Nauczyciel musi także wykazać się gotowością do wycofywania się z zadań, które dziecko jest w stanie wykonać samodzielnie, a udzielenia pomocy w miarę dochodzenia przez nie do nieznanych mu obszarów wiedzy” (Wood 2006: 265).

\section{Konkluzja}

Otwarcie kultury szkoły na nową jakość (konstruktywizm społeczno-kulturowy), przekraczanie wcześniej ustalonych pragmatycznych wzorów działania, zmiana stylu myślenia i działania nauczycieli są możliwe. Heurystyczny potencjał teorio-metody Wygotskiego może się stać instrumentem odnowy edukacji. Trzeba jednak stworzyć krytyczną przestrzeń dla zmiany uczącej się społeczności, przygotować grunt dla otwartości na „nieprzewidywalną nowość", uzyskać zgodę na odkrywanie nowych kontekstów i przewidzieć czas na przepracowanie zmiany (Zamorska, Krzychała 2012; Filipiak 2020). Aby nauczyciele „(po)myśleli” szkołę na nowo, podjęli wyzwanie otwarcia kultury szkoły na nową jakość i zaangażowali się w proces zmiany, konieczne jest także przygotowanie „gruntu”, praca $\mathrm{z}$ ich osobistymi teoriami i przekonaniami.

Przygotowanie nauczycieli do zrozumienia wyrafinowanej poznawczo i niełatwej koncepcji nauczania rozwijającego systemu Elkonina-Dawidowa, opartej na teorio-metodzie Wygotskiego, podjęto w Laboratorium Zmiany Edukacyjnej Uniwersytetu Kazimierza Wielkiego w Bydgoszczy w związku z realizowanym projektem „Nauczanie rozwijające we wczesnej edukacji według Lwa S. Wygotskiego". Aby wejść w rolę interwencjonisty, gotowego do budowania rusztowania dla myślenia i rozumowania dziecka, konstruowania sytuacji edukacyjnych ukierunkowanych na strefę najbliższego rozwoju, umiejętności stawiania dzieciom zadań rozwojowych według Dawidowa, konieczne było przeprowadzenie serii sesji developmental teaching (Filipiak, Lemańska (red.) 2015; Filipiak 2020). Ten etap ujawnił trudności i opór nauczycieli wobec nowego modelu pracy z dziećmi. 
Modyfikacja stylu i sposobu prowadzenia dialogu, interwencji formatywnych, ,wrażliwego nauczania” jest jednak konieczna. W przeciwnym razie koncepcja nauczania rozwijającego może być działaniem pozornym, jak pokazały to niektóre doświadczenia z wdrażania opartego na koncepcji Wygotskiego pakietu Klucz do uczenia się (Key to learning) w przedszkolach. Działania w Laboratorium Zmiany Edukacyjnej są kontynuowane.

\section{Literatura}

Brown A.I., Ferrara R.A. (1994), Poznawanie stref najbliższego rozwoju. W: A. Brzezińska, G. Lutomski (red.), Dziecko w świecie ludzi i przedmiotów. Poznań, Zysk i S-ka.

Bruner J.S. (2006), Kultura edukacji. Kraków, Universitas.

Brzezińska A. (2000), Społeczna psychologia rozwoju. Warszawa, Wydawnictwo Naukowe Scholar. Davydov V.V. (1996), The theory of development al teaching. Moskwa, Intor.

Dylak S. (2000), Konstruktywizm jako obiecujaca perspektywa ksztatcenia nauczycieli. W: H. Kwiatkowska, T. Lewowicki, S. Dylak (red.), Wspótczesność a kształcenie nauczycieli. Warszawa, WSP ZNP.

Elkonin D.B. (1989), Izbrannyje psichołogiczeskije trudy. W: W.W. Dawidow, W.P. Zinczenko (red.), Trudy djejstwiitielnych czlenow i czlenow - korrespondientow Akademii piedagoiczeskich nauk SSSR. Moskwa.

Filipiak E. (2011), Stownik pojęć kluczowych. Z Wygotskim i Brunerem w tle. Bydgoszcz, Wydawnictwo UKW.

Filipiak E. (2012), Rozwijanie zdolności uczenia się. Z Wygotskim i Brunerem w tle. Sopot, Gdańskie Wydawnictwo Psychologiczne.

Filipiak E. (2015), Budowanie rusztowania dla myślenia i uczenia się dzieci w perspektywie spoteczno-kulturowej teorii Lwa S. Wygotskiego. W: E. Filipiak (red.), Nauczanie rozwijajace we wczesnej edukacji wedtug Lwa S. Wygotskiego. Od teorii do zmiany w praktyce. Bydgoszcz: Agencja Reklamowo-Wydawnicza ArtStudio.

Filipiak E. (red.) (2015), Nauczanie rozwijajace wedtug Lwa S. Wygotskiego we wczesnej edukacji dziecka. Od teorii do zmiany w praktyce. Bydgoszcz, Agencja Reklamowo-Wydawnicza ArtStudio.

Filipiak E. (2018a), Badanie potencjału możliwości uczenia się dzieci - eksperyment nauczajacy. „Problemy Wczesnej Edukacji”, 3.

Filipiak E. (2018b), Cultural-historical theory by Lev S. Vygotsky: strategies of studies on children's learning and development. From theory to change in practice. „Forum Oświatowe”, 30(60).

Filipiak E. (2020), Connaitre les croyances des enseignants pour changerleur comprehension de ce qui se passe en classe. L'exemple du Laboratoire de channgement educatif en Pologne. W: A. Bouvier, M.-J. Sanselme (eds.), Croyances et pratiques professionnelles des enseignants. Sevres, France Education International.

Filipiak E., Lemańska E. (red.) (2015), Model nauczania rozwijającego we wczesnej edukacji wedtug Lwa S. Wygotskiego. Gotowość studentów i nauczycieli. Możliwości aplikacji. Raport tematyczny z realizacji projektu. Bydgoszcz, Akademickie Centrum Kreatywności, ArtStudio.

Giest H. (2001), Instruction and Learning in Elementary School. W: M. Hedegaard (ed.), Learning in Classrooms: A Cultural - Historical Approach. Aarhus, Aarhus University Press. 
Giest H., Lompscher J. (2003), Formation of Learning Activity and Theoretical Thinking in Science Teaching. W: V. Ageev, B. Gindis, A. Kozulin, S. Miller (eds.), Vygotsky's Theory and Culture of Education. New York, Cambridge University Press.

Gołębniak B.D. (2005), Konstruktywizm - moda, ,nowa religia” czy tylko/aż interesujaca perspektywa poznawcza i dydaktyczna? „Problemy Wczesnej Edukacji”, 1(1).

Hedegaard M., Fleer M. (2013), Play, Learning, and Children's Development. Everyday Life in Families and Transition to School. Cambridge, Cambridge University Press.

Ivić I. (2000), Lew Siemionowicz Wygotski. W: Cz. Kupisiewicz (red.), Myśliciele o wychowaniu. Przekład z ang., fr. D. Karbowska i in. T. 2. Warszawa, Graf-Punkt.

Karpov Y.V. (2014), Vygotsky for Educators. Cambridge, Cambridge University Press.

Klus-Stańska D. (2008), Mitologia transmisji wiedzy, czyli o konieczności szukania alternatyw dla szkoły, która amputuje rozum. „Problemy Wczesnej Edukacji”, 2(8).

Klus-Stańska D. (2018), Paradygmaty dydaktyki. Myśleć teoria o praktyce. Warszawa, Wydawnictwo Naukowe PWN.

Rogoff B. (2003), The Cultural Nature of Human Development. New York, Oxford University Press.

Schaffer H.R. (2005), Psychologia dziecka. Warszawa, Wydawnictwo Naukowe PWN.

Shotter J. (1994), Psychologia Wygotskiego: wspólna aktywność w strefie rozwoju. W: A. Brzezińska, G. Lutomski (red.), Dziecko w świecie ludzi i przedmiotów. Poznań, Zysk i S-ka.

Smykowski B. (2000a), Podejście rozwojowe do badania form zachowań. W: A.I. Brzezińska (red.), Z Wygotskim w tle. Torun, Wydawnictwo Uniwersytetu im. Mikołaja Kopernika. Nieobecne dyskursy, cz. 6.

Smykowski B. (2000b), Prymitywizm a wyższe formy zachowań. W: A.I. Brzezińska (red.), Z Wygotskim w tle. Torun, Wydawnictwo Uniwersytetu im. Mikołaja Kopernika. Nieobecne dyskursy, cz. 6.

Smykowski B. (2017), Eksperymentalna metoda podwójnej stymulacji w diagnozowaniu gotowości dzieci do uczenia sie pod kierunkiem. „Psychologia Wychowawcza”, 53(11).

Stemplewska-Żakowicz K. (1996), Osobiste doświadczenie a przekaz społeczny. O dwóch czynnikach rozwoju społecznego. Wrocław, Fundacja na Rzecz Nauki Polskiej.

Wood D. (1995), Społeczne interakcje jako tutoring. W: A. Brzezińska, G. Lutomski, B. Smykowski (red.), Dziecko wśród rówieśników i dorostych. Poznań, Zysk i S-ka.

Wood D. (2006), Jak dzieci ucza się i myślą. Społeczne konteksty rozwoju. Kraków, Wydawnictwo Uniwersytetu Jagiellońskiego.

Wygotski L.S. (1971), Wybrane prace psychologiczne. Warszawa, PWN.

Wygotski L.S. (1989), Myślenie i mowa. Tłum. E. Flesznerowa, J. Fleszner. Warszawa, PWN.

Wygotski L.S. (2002), Wybrane prace psychologiczne. T. 2: Dzieciństwo i dorastanie. A. Brzezińska, M. Marchow (red.). Poznań, Zysk i S-ka.

Zamorska B., Krzychała S. (2012), Zamknięte i otwarte zmiany kultury szkoły. W: B.D. Gołębniak, H. Kwiatkowska (red.), Nauczyciele. Programowe (nie)przygotowanie. Wrocław, Wydawnictwo Naukowe DSW.

Zuckerman G. (2003), The Learning Activity in the First Years of Schooling: The Developmental Path Toward Reflection. W: V. Ageev, B. Gindis, A. Kozulin, S. Miller (eds.), Vygotsky's Theory and Culture of Education. Cambridge, Cambridge University Press.

Zuckerman G., Vengier A.L. (2015), Development of Learning Self-dependence. Moscow, Авторский Клуб.

Zwiernik J. (2015), Podejścia badawcze w poznawaniu wiedzy dziecka. „Teraźniejszość - Człowiek - Edukacja", 18(69). 